\title{
Historians Respond to Whitehouse et al. (2019), "Complex Societies Precede Moralizing Gods Throughout World History"1
}

Edward Slingerland, ${ }^{2}$ Department of Asian Studies, University of British Columbia

M. Willis Monroe, Department of Asian Studies, University of British Columbia

Brenton Sullivan, Department of Religion, Colgate University

Robyn Faith Walsh, Department of Religious Studies, University of Miami Daniel Veidlinger, Comparative Religion and Humanities, California State University, Chico

William Noseworthy, Department of History, McNeese State University Conn Herriott, Institute of Archaeology, Hebrew University of Jerusalem Ben Raffield, Department of Archaeology and Ancient History, Uppsala University

Janine Larmon Peterson, Department of History, Marist College Gretel Rodríguez, History of Art and Architecture, Brown University Karen Sonik, Department of Art and Art History, Auburn University William Green, Department of Religious Studies, University of Miami Frederick S. Tappenden, St. Stephen's College, at the University of Alberta Amir Ashtari, University of British Columbia

Michael Muthukrishna, Department of Psychological and Behavioural Science, London School of Economics

Rachel Spicer, Department of Psychological and Behavioural Science, London School of Economics

\footnotetext{
${ }^{1}$ This commentary has been accepted for publication in the Journal of Cognitive Historiography. This draft is an un-edited preprint, and might differ slightly from the final, published version. Please do not cite this version without permission. You can request the complete, final manuscript, by contacting the corresponding author, Edward Slingerland (edward.slingerland@gmail.com).

${ }^{2}$ Corresponding author: edward.slingerland@ubc.ca. Edward Slingerland is Distinguished University Scholar and Professor of Asian Studies at the University of British Columbia.
} 


\section{Abstract}

As historians, archaeologists, and database analysts affiliated with the Database of Religious History (DRH; religiondatabase.org), we share with the Seshat: Global History Databank team, authors of a recent study published in Nature, an excitement about the potential for deep and sustained collaborations between historians and analysts to answer big questions about human history. We have serious concerns, however, by the approach to the quantitative coding of historical data taken by the Seshat team, as revealed in the backing data (seshatdatabank.info/nature), as well as by a lack of clarity concerning the degree of involvement of expert historians in the coding process. The apparent lack of appreciation for historical scholarship that this coding strategy displays runs the risk of permanently alienating the community of academic historians, who are essential future collaborators in any project devoted to large-scale historical data analysis. In the present commentary, we present a preliminary critical review of their latest article, "Complex Societies Precede Moralizing Gods Throughout World History" (2019).

\section{Keywords}

Database of Religious History (DRH); interdisciplinary collaboration; method and theory in historical research; quantitative coding; Seshat: Global History Databank

\section{Introduction}

As historians, archaeologists and database analysts affiliated with the Database of Religious History (DRH; religiondatabase.org), we share with the Seshat: Global History Databank team, authors of a recent study published in Nature, an excitement about the potential for deep and sustained collaborations between historians and analysts to answer big questions about human history. We have serious concerns, however, by the approach to the quantitative coding of historical data taken by the Seshat team, as revealed in the backing data (seshatdatabank.info/nature), as well as by a lack of clarity concerning the degree of involvement of expert historians in the coding process. 
Large-scale, quantitative databases of the cultural/historical record are a relatively recent innovation. There are currently no shared standards concerning best practices, such as how to manage trade-offs between rate of data collection and data quality or expert-sourced vs. Research Assistants (RA)-sourced data, documentation of expert data vetting, etc. ${ }^{3}$ Nonetheless, we feel that the approach adopted by the Seshat team has - at least with regard to the data reported in this most recent study - produced codings of crucial variables that are systematically flawed and unlikely to stand up to close scrutiny. Most worrying is the fact that the apparent lack of appreciation for historical scholarship that this coding strategy displays runs the risk of permanently alienating the community of academic historians, who are essential future collaborators in any project devoted to large-scale historical data analysis.

We separately provide a representative list of specific coding issues as $\mathrm{S} 1$, accessible at https://hecc.ubc.ca/response-to-whitehouse-et-al/. A quick reality check, where we re-coded the religion and ritual variables for 12 polities from the Middle Yellow River Valley (MYRV) using expertgenerated and expert-vetted codes from the DRH, found that in only under a third of cases the codings from Seshat agreed with the expert data found within the DRH (summary provided in Table 1 below). ${ }^{4}$

${ }^{3}$ An initial attempt to forge such standards is represented by Slingerland, Atkinson, Ember, Sheehan, Muthukrishna, Bulbulia and Gray (under submission); for a critique of the contemporary CSR big data neglect of the historical sciences and need for humanistic expertise, see Ambasciano and Coleman 2019.

${ }^{4}$ Full results available as S3 at https://hecc.ubc.ca/response-to-whitehouse-et-al/. 


\begin{tabular}{rlcc}
\hline Seshat NGA & Date & DRH Entries & Agreement \\
\hline \hline Late Shang & $1250-1045 \mathrm{BCE}$ & 3 & $6.67 \%$ \\
\hline Western Zhou & $1122-771 \mathrm{BCE}$ & 2 & $30 \%$ \\
\hline Jin & $794-489 \mathrm{BCE}$ & 1 & $40 \%$ \\
\hline Wei & $488-223 \mathrm{BCE}$ & 6 & $25 \%$ \\
\hline Imperial Qin & $338-207 \mathrm{BCE}$ & 6 & $25 \%$ \\
\hline Western Han & $202 \mathrm{BCE}-9 \mathrm{CE}$ & 5 & $45 \%$ \\
\hline Eastern Han & $25-220 \mathrm{CE}$ & 5 & $31 \%$ \\
\hline Western Jin & $263-317 \mathrm{CE}$ & 2 & $0 \%$ \\
\hline Northern Wei & $386-534 \mathrm{CE}$ & 3 & $40 \%$ \\
\hline Sui & $581-618 \mathrm{CE}$ & 1 & $40 \%$ \\
\hline Early Tang Dynasty & $617-763 \mathrm{CE}$ & 3 & $40 \%$ \\
\hline Late Tang Dynasty & $763-907 \mathrm{CE}$ & 2 & $40 \%$ \\
\hline & & Total & $30.22 \%$ \\
\hline
\end{tabular}

Table 1. Comparison of Seshat coding of religion and ritual variables in early MYRV with expert-generated or expert-vetted codes from the Database of Religious History (DRH).

These coding errors undermine the analysis presented in Whitehouse et al. (2019). For instance, a crucial datapoint for Whitehouse et al. (2019), a supposed instance of a Natural Geographic Area (NGA) that possessed writing before a moralizing high god, is the Middle Yellow River Valley (MYVR). This is because the Late Shang polity was coded as lacking a moralizing god, based on a citation from Robert Eno, an expert on the area. Eno's opinion, however, is in the minority in the field, as anyone familiar with the literature would know. A look at expert-generated, pre-coded data from the DRH shows that Eno's view (https://religiondatabase.org/browse/299/\#) is contradicted by the other two entries on the Shang, by the eminent scholars David Keightley (https://religiondatabase.org/browse/23/\#/) and Lothar von Falkenhausen (https://religiondatabase.org/browse/187/\#/). Re-coding this variable as 1 
(based on majority opinion) or weighting it as .66 would seriously undermine Whitehouse et al.'s conclusion.

Another error related to the crucial first appearance of moralizing gods can be found in the Susiana NGA. The first instance of a "high god" in the Susiana NGA is reported during the Akkadian Empire period $\left(23^{\text {rd }}\right.$ century $\mathrm{BCE}$ ), where the high god during this period is marked only as "active" by Seshat, i.e. impacting human affairs but not interested in their morality. However, temple hymns attributed to Enheduana, the daughter of Sargon, the founding king of the Akkadian period, mention the sun god Shamash's ability to render judgement over the entire population of the land (Halton and Svärd 2018: 76). Perhaps even more importantly, Seshat includes enforcement of "curses" as part of their moralizing framework, and the royal inscriptions of the same Akkadian kings are replete with curses invoking Shamash to curse anyone who might remove or deface their inscriptions (D. Frayne 1993). This coding error is significant because the first instance of a "moralizing" god in the Seshat dataset for Susiana does not occur until the Achaemenid period, almost two thousand years later. This two-thousand-

year error, if corrected, would further undermine Whitehouse et al.'s analysis.

The problems with the Seshat approach, however, go far beyond these specific instances of errors in scholarship. More fundamentally, the Seshat method of gathering historical data, in our view, simply cannot, by its very nature, produce reliably useful historical scholarship. The study of historic, ancient, and prehistoric institutions, technologies, and belief systems demands that coders familiar with the relevant scholarship harness the full spectrum of available materials, including relevant textual or archaeological primary source materials. The basic ethos and methodology of the Seshat project militate against such rigor and care - through, we wish to emphasize, no fault of their hardworking and serious RAs, who seem to have been burdened with an impossibly challenging task given their training and the tasks and deadlines involved.

\section{Claims Concerning Data Vetting}

The description of the coding procedure for the religion and ritual variables provided by Whitehouse et al. (from the Methods section of their paper) reads as follows: 
Data collection for the religion and ritual variables involved matching each fully trained research assistant with one or more Seshat experts. Seshat experts provided guidance on how to delineate the temporal and geographical boundaries of the polity, assembled an initial reading list and, where necessary, helped to interpret some of the key historiographical debates associated with the variables. Research assistants then populated the variables with data and presented this to the Seshat experts for review. The comments and suggestions made by the experts were then implemented by the research assistants. The next stage required a second team of fully trained research assistants to go over the gathered data and to conduct a series of quality checks, including vetting of the footnotes and the use of correct syntax for the machine-readable part of the data. Finally, this checked dataset was given to the Seshat experts for review. The coding of religion and ritual data required the input of experts every step of the way, given the frequent need for complex and nuanced interpretation of the evidence. By contrast, the data required for the social complexity variables frequently consisted of facts that research assistants could procure with less supervision, allowing expert input and review to occur at a later stage of the process. [note: emphasis added]

With regard to the social complexity variables, one wonders when and how the Seshat team plans to allow "expert input and review to occur," as well as why one would use unvetted data in a published analysis if one sees a role for expert input and review. With regard to the religion and ritual variables, however, the authors are aware that the "frequent need for complex and nuanced interpretation of the evidence" demands expert involvement "every step of the way."

A look at the backing data on the Seshat site at the time of publication (http://seshatdatabank.info/nature/) shows, however, that only a small portion of the coding is credited to a named expert vetter: $13 \%$ of polities in 
fact have both sets of variables checked, $24 \%$ have only one checked, and $63 \%$ have no expert vetting at all..$^{5}$ In response to a query noting this discrepancy, the authors have claimed that their backing data at the time of publication was not accurate, and they have since added more expert vetting attributions to the database, in addition to changing many of the original vetting attributions (see below). Even this updated account is problematic: for certain NGAs the Seshat team has added the names of experts at the top of each polity with the phrase, "verified key data regarding earliest appearance of moralizing gods/doctrinal rituals." Even if these scholars have verified this data concerning "earliest appearance," this statement can logically only apply to one polity - whichever was characterized by this earliest appearance. Pasting the phrase into all polities in the NGA appears to merely have the function of inflating the reported percentage of vetted polities.

A perhaps even more worrying phenomenon is that even the partial expert vetting claimed for Seshat data appears to be overstated. For instance, in the backing data provided to Nature reviewers, Prof. Vesna Wallace appears as the most prolific expert vetter, described as having vetted the religion and ritual variables for 49 polities in 7 NGAs (presumably twice, and in constant contact with the RA performing the coding, as described in the Methods section). To put this in perspective, this translates to polities stretching in time from $1400 \mathrm{BCE}$ to the $20^{\text {th }}$ century, and from Mongolia to Cambodia. After our e-mail of March 25, 2019 to the authors, they appear to have gone through the Seshat data provided to Nature referees and systematically changed their claim about Prof. Wallace having vetted all of the religion and ritual variables to this statement: "verified key data regarding earliest appearance of moralizing gods/doctrinal rituals." ${ }^{6}$ Similar changes were made to vetting attributions to other experts and polities.

In their Methods section, Whitehouse et al., after describing their process for coding and providing coding justifications (references or personal communications from experts), state:

All data are linked to scholarly sources, including peer-reviewed publications and personal

\footnotetext{
${ }^{5}$ A spreadsheet listing all of the relevant Seshat polities, providing a 0 score for no vetting, a 1 for a single set of variables vetted, and a 2 for both sets vetted, as claimed, is available as S2 here: https://hecc.ubc.ca/response-to-whitehouse-et-al/.

${ }^{6}$ Interested readers can find screenshots from the Seshat site at the time of publication as S4 here: https://hecc.ubc.ca/response-to-whitehouse-et-al/.
} 
communications from established authorities. On occasions when Seshat experts disagree on a particular coding, we kept a record of disagreements so that analyses could be run taking into account contrasting interpretations. Once used for the purposes of data analysis and publication, that version of the dataset was 'frozen' so that it could be inspected by others and used for the purposes of replication. Nevertheless, the data in Seshat continually evolves, as new sources are discovered and as new Seshat experts contribute additional layers of interpretation.

Seshat is an on-going project, with continuous additions and emendations. This statement leads one to assume, however, that - however much the main site might change over time - the version of the Seshat site that was spun off and provided to Nature reviewers and to the press during pre-publication, found at http://seshatdatabank.info/nature/, would remain static. This would allow the rationale behind the codings actually used in the study to be evaluated, the degree of expert vetting assessed and identity of expert vetters ascertained, and replication attempts performed. It is concerning to us that this Nature-tagged version of the site has been, in fact, systematically altered, we also presume that the responsible Nature editor and referees were not informed of this change, and would welcome a rationale from the Seshat team. We are also happy to provide screenshots of the relevant NGAs to the Seshat team at time of publication if they require assistance in restoring this version of the site to its original form.

In any case, Prof. Wallace, has, when contacted by a member of our team, expressed surprise at any mention of her as expert vetter on the Seshat site, noting that she had no part in any aspect of coding, vetting or recommendation of sources, and that most of the NGAs where she is listed are entirely outside her area of expertise. ${ }^{7}$ While this may be an isolated case, this instance of misrepresentation concerning their most prolific expert vetter, combined with the subsequent alteration of backing data on the Seshat site, seems to us serious enough to warrant a complete review and verification of the Seshat expert vetting claims.

${ }^{7}$ Personal communications to Brenton Sullivan and Edward Slingerland (April 2 and April 4, 2019). According to Wallace, her involvement with the Seshat project was limited to attending a basic informational session and then having a private conversation with one of the Nature authors about one or two basic issues in Indian and Mongolian Buddhism. 
We have earlier communicated to the team behind this article our concern with regard to misleading statements about their data vetting procedures in a previous publication (Turchin et al. 2018), where a claim in the main article that all of the codings were vetted becomes a much weaker claim that codings were checked "when possible" or "when necessary" in the Supplementary Information. Our suggestion that they submit an edit request to the journal to fix this discrepancy was rebuffed. The fact that an even more starkly misleading exaggeration appears in this latest publication creates broader worries about assurances concerning data coding and vetting procedures from the Seshat team.

Even a cursory glance at the coding justifications makes it clear that that this haphazard process has undermined data quality: large swathes of the religion and ritual codings are incorrect, missing proper justifications, or based upon irrelevant sources, and the coding justifications in general reflect a minimum amount of research on the part of RAs, most of whom lack any specific area expertise. This lack of expertise leads to coding errors that undermine the authors' analysis.

Reasonable people can disagree about the relative merits of RA-based versus expert-based coding. What no one should find objectionable, however, is the idea that one must be clear about which strategy one is pursuing, so that outside researchers can decide for themselves how seriously to take one's data. Below we will walk through some of the systematic problems created by the Seshat strategy, with S1 (https://hecc.ubc.ca/response-to-whitehouse-et-al/) detailing particularly important or egregious errors in coding or sourcing.

\section{Lack of Intercoder Reliability Measures}

In their Methods section, the authors note that, "On occasions when Seshat experts disagree on a particular coding, we kept a record of disagreements so that analyses could be run taking into account contrasting interpretations." A table in their online Supplementary Information ${ }^{8}$ indicates that this sort of expert disagreement was only encountered in 506 cases, a mere $1.1 \%$ of their total data coverage. This suggests an impressive degree of inter-expert agreement to an unwary Nature reader. In fact, it simply reflects the fact, clear to anyone reading the backing data, that the

8 "Supplementary Online Material Table 1 | Breakdown of Supplementary Dataset 1 data analysed by type of coding uncertainty." 
Seshat team rarely consulted more than one expert or expert-produced secondary source.

The backing data reveals that, in the vast majority of cases, the coding of variables was performed by a single RA, usually with no knowledge of the field, relying upon a single expert personal communication or published work - although the specificity and scholarly quality of the latter varies considerably. In a source such as the DRH, multiple overlapping entries, such as those by Eno, Keightley, and von Falkenhausen noted above, give one both a weighted value that can be used in an analysis and a measure of intercoder reliability. With the Seshat data, we are mostly left having to trust the judgment of an RA coder with no specialized knowledge of the field, who in turn is relying upon a personal communication from an expert or a single scholarly source they happened to discover. This illustrates the danger of parachuting an RA with no knowledge of a field into a vast and complicated body of primary, secondary, and tertiary literature: they have no way of judging the representativeness of the sources they first happen to come across in their research, and may up coding a variable based on an idiosyncratic scholarly opinion.

\section{Paucity of Actual Observations: Data Pasting}

It is also commonly the case in the Seshat databank that "observations" of a particular slice of space and time, in the form of a coding of a variable relying upon a personal communication from an expert or an expert source, is simply pasted into later polities in the same NGA without any justification or additional research indicating that such an imputation is valid (data pasting).

A review of the MYRV religion and ritual variables, for example, shows that the 110 data points ( 5 variables x 22 polities) are supported by only 16 independent observations - most consist of a simple pasting in of the previous polities' data. Since these imputations are being done by an RA with no specialized knowledge of the area, an expert comment or citation would be needed to confirm that earlier observations are still valid in a polity thousands of years later. We have nothing of that sort, which suggests that the RA, working quickly, is looking at place- and time-relevant sources or expert comments every millennium or so. This produces such absurdities as using an observation about Late Shang (1800 BCE) ritual practice to code the "ritual frequency" variable for every polity from the Western Zhou (1122 BCE) to the Ming (1643 CE). To put this another way, all of the 
coding of the religion and ritual variables for about 5000 years of Chinese history, which the Seshat team proudly presents as representing a plethora of data points, in fact represents interpretations of a few personal communications and 5-6 citations of mostly inappropriate secondary literature; these few, inaccurate measurements were then repeated verbatim, creating the illusion of complete historical coverage.

Similarly, an overall review of the coding for the variable high gods (creator gods) shows that there are only 50 unique accompanying descriptions that justify the coding of this variable across the entire database of 298 different polities. The maximum number of unique justifications for a single NGA was 9 for the Konya Plain (Central Anatolia, contemporary Turkey); however, this region contains 30 polities. Whether high gods are present or absent is unknown for the majority of the oldest polities, and 106 polities with an unknown classification for high gods have no sources for this categorization (see Fig. 1). Only 20 polities with unknown status of high gods have a source justifying their coding.

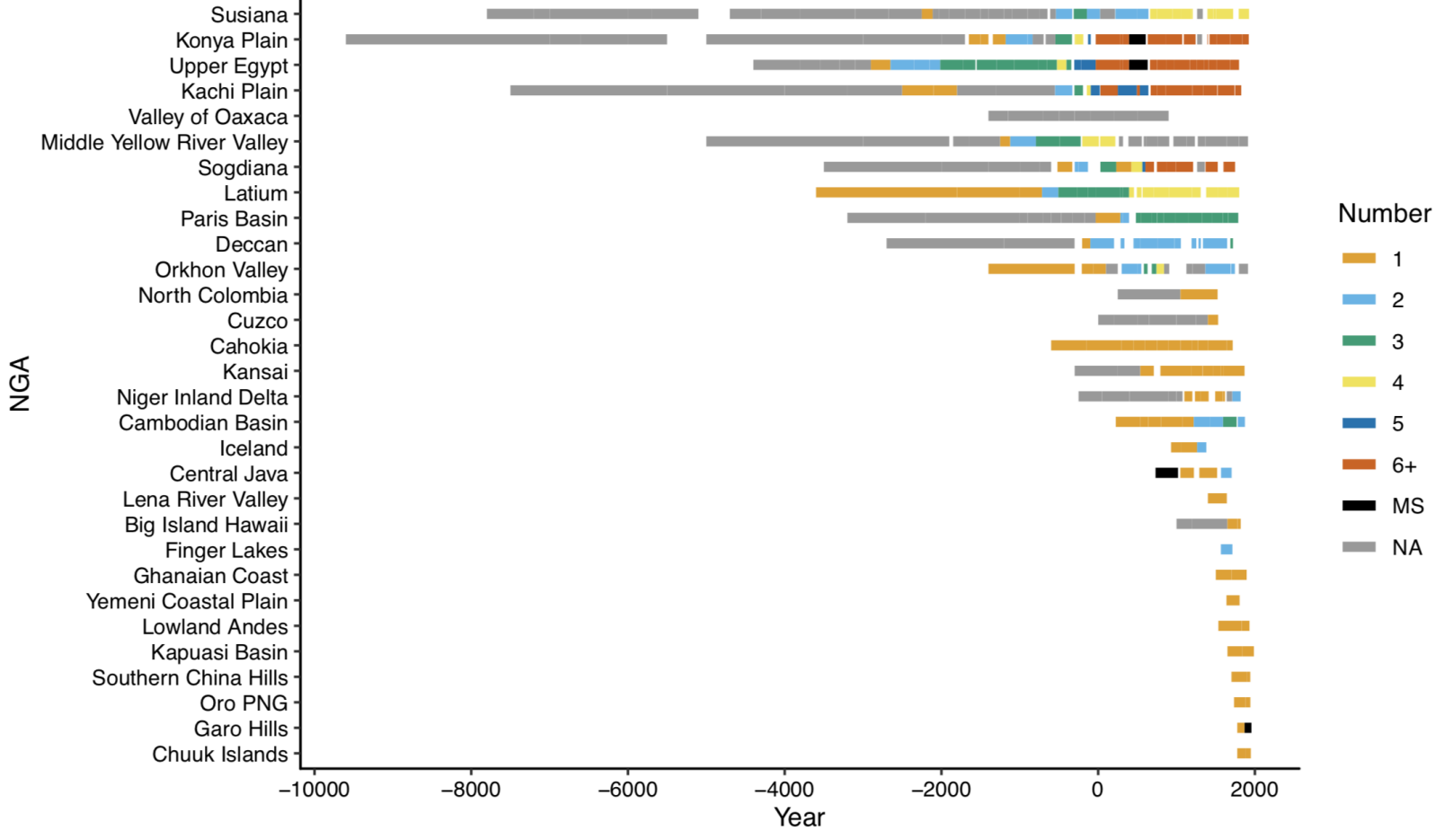

Fig 1 . The time periods of each coding justification (if only 1 ) or set of coding justifications $(2-6+)$ for the variable high gods (creator gods) per natural geographic area (NGA). For some polities the presence/absence of high gods (creator gods) was categorized as "suspected unknown" or "unknown" and had no coding justification; as these variables are 
treated as missing values during analysis conducted by Whitehouse et al., they were categorized as NA. We found that some variables with classifications of "moralizing", "active" and "inactive" were also missing source texts, justifying their categorization, and these are labelled in the figure as MS.

\section{Paucity of Actual Observations: Data Filling}

A related practice is the use of generalized histories to create what appear to be discrete geographical and temporal points of data that are not in fact covered by the citation (i.e., data filling). This often takes the form of a mischaracterization of, and excessive reliance upon, generalist historical sources, or using broad archaeological surveys to fill in data on specific archaeological sites.

The Susiana entry is a good example of this citational malpractice. Many of the citations used to support answers for different periods of Susiana derive from general histories of the entire Ancient Near East and are for the most part actually concerned with evidence from southern Mesopotamia, not Susiana (that is, ca. $700 \mathrm{~km}$ away). Historical sources should be measured by their closeness to an observation of archaeological or textual data. Generalized histories are neither, and often cover large ranges of time and space which makes them insufficient evidence for discrete data points. More worrying is the use of non-specialist general historical summaries that cover millennia of time in a few pages. These citations often take the form of one introductory chapter covering the entire history of a concept in a book containing contemporary articles on that concept. The Susiana entry uses at least three of these types of chapters to support discrete data points.

To take another example, the RA coding religion and ritual for the Orkhon Valley NGA in the Late Qing polity cites a long passage from Buddhaghosa's Visuddhimagga, an important, classical text to be sure, but one that derives from Pali Buddhism. Pali Buddhism is found in South and Southeast Asia, and is so remote from the Buddhism of the Orkhon Valley at this time as to be irrelevant. Similarly, for religion's enforcement of fairness, the RA cites Damien Keown's Very Short Introduction to Buddhism: "One of the best ways for a layman to earn merit is by supporting the order of monks. This can be done by placing food in the bowls of monks as they pass on their daily alms round [...]" (Keown 2013: 43). There were never daily alms rounds in Qing China. This is a good instance of an introductory, generalist work being used to inaccurately code a specific slice of space and time. 
We see a similar problem in the entry on Classical Angkor, where the RA uses a very general introduction to Hinduism (Shattuck 1999) as the main source for information about the religion of the region. Hinduism in India, however, is rather different from Hinduism in classical Cambodia, and it is surprising that they did not refer to the various articles that attempt to put Hinduism into the Southeast Asian context that is relevant to this piece. They even specifically quote from the book, "in this era, the belief in a single life span was replaced by a system of reincarnation called samsara, the cycle of rebirths" (Shattuck 1999: 29), despite the fact that the era being referred to in this passage is $5^{\text {th }}$ century BCE India, not $11^{\text {th }}$ Century CE Cambodia.

Religion, in its institutional, doctrinal, and ritual aspects, is constantly evolving. Databases are a tool that can allow researchers to trace these changes, rather than presenting religion as monolithic over place and time. Seshat's reliance on generic sources pasted across wide spans of space and time makes it an unhelpful tool for this purpose. Take, for instance, the entries on Latium and on Byzantium during Late Antiquity and the Middle Ages, which code a hegemonic Christian Church rather than the Christian churches that existed, and ignores the fractures and challenges both within what came to be called Roman Catholicism and its relationships with Eastern Orthodox church officials and secular rulers. Every single entry in the "Religion and Rituals" section for Latium from 312-1527 CE (although Christianity existed well before Constantine's conversion, dated in Seshat to 312) and the Eastern Roman Empire/Byzantine empire from 395-1204 (although the empire continued through 1453 when Constantinople succumbed to the Ottoman Turks) is exactly the same. Every entry about "supernatural enforcement" of reciprocity, group loyalty, and fairness, as well as that of "high gods," are based on three quotations from two encyclopedias. Seshat's practice of using tertiary sources (i.e., encyclopedias or dictionaries) and applying brief snippets from these sources across wide swathes of time and place promulgates a false belief in a static Christian religiosity and organization, which is extremely misleading for inexpert users and not useful for academic researchers.

Turning to Seshat's data-gathering with regard to prehistoric archaeological sites, the attempt of this project to lump together and average out the archaeological evidence from disparate sites in a large region and timespan has produced sparse and highly unreliable data. The information 
on the earliest period of the Konya Plain, for instance, is heavily flawed and very limited, and draws attention to serious problems in the fundamentals of the Seshat data-gathering approach. Seshat works from the faulty premise that prehistoric sites in the Konya Plain - and, indeed, all of the regions that it covers - can be treated as a group. Therefore, even if Seshat's datagathering had been based on careful and exhaustive research (which was not the case in most of the regions we observed), such a perspective would always produce data that mask so much variability as to be virtually meaningless. Furthermore, eliminating the earliest periods of prehistory from NGAs severely hobbles Seshat's aspiration of studying human diversity and evolution.

We see this also in the treatment of the "Icelandic Commonwealth" (930$1263 \mathrm{CE}$ ). Several of the comments on the religion and ritual variables for pre-Christian beliefs simply state that "Norse morality[/religion] is relatively poorly understood, especially as much of what we know about Norse beliefs generally was recorded by Christian authors." While the limitations and biases of the available source materials, which were compiled during the medieval period, must of course be acknowledged, the last few decades have seen countless publications on the pre-Christian belief systems of the Viking Age (Price 2002; Jennbert and Raudvere 2006; Raudvere and Schjøt 2012; Sundqvist 2015). Aside from a few cursory references to Eddic sources (obtained from an introductory guide to Old Norse mythology), there is no evidence to suggest that those responsible for compiling the entry have tried to consult this material. The discussion of medieval Christianity is little better, relying heavily on references to The New Catholic Encyclopedia. By failing to engage with the wealth of available literature on the Christianization process and the medieval Church in Scandinavia, the entry rides roughshod over years of scholarly research in this field.

It is our view that initiatives seeking to marry quantitative and qualitative historical research must work from the ground up, focusing on specific excavation reports, religious groups, primary texts or rituals, and thereby amassing more granular, accurate and meaningful data on each. This would allow many of the numerous blanks in a databank to be filled in, and with data of actual value. The practice of deriving discrete data points from general historical studies or bundles of disparate archaeological sites misses the critical observations and boundaries necessary in working with primary sources in the archaeological and textual record. 
The widespread reliance on data filling and data pasting by the Seshat team means that the majority of their data, at least when it comes to the crucial religion and ritual variables, is essentially meaningless. Coding MYRV Han imperial court ritual frequency based upon a comment about a Shang Dynasty practice will result in an accurate data point at a more or less chance rate. For large expanses of their data, the Seshat team has spent enormous amounts of time and energy and funding to have RAs laboriously paste in scholarly observations and codings that are completely irrelevantbeing either too specific or too generic — to the polities being analyzed.

We would like to emphasize again that we have no desire to question the abilities or work ethic of the RAs responsible for this data, who appear to have done the best they could have given their training and the nature of the deadlines that were no doubt imposed upon them. The sort of systematic errors and oversimplifications we see in the Seshat: Global History

Databank fall naturally out of its structure and coding strategy, which leads us to our next point.

\section{Basic Approach to the Historical Record}

The Seshat project consists of a series of NGAs, each of which is divided into a series of chronological periods that range (on average) from approximately $100-300$ years in length. These $100-300$-year periods become the basis of the Seshat data; each period is populated with data points relevant to the NGA for that particular historical window, thus causing historical information to be flattened into distinct 100-300-year blocks. By structuring the data in this way, the Seshat project seeks to map diachronic historical developments over several periods. Given this data structuring, the definition of these periods is of foundational importance; if the demarcation of the periods does not adequately reflect the historical record of the NGA, then the quality of the historical data is skewed.

From a historian's point of view, this approach to the historical record is problematic in several ways. To begin with, while there are pragmatic reasons for splicing an NGA into a series of successive 100-300-year periods, in the end this project design flattens the historical data into singlepoint representations. There is no room, for instance, for historical trajectories/movements that do not fit neatly into the prescribed periods. Moreover, the model of successive periods makes it impossible to capture historical nuance, gradation, and gradual development within the 100-300- 
year periods themselves. In the end, Seshat has designed its historical database in a way that does not adequately contend with the difficulties and nuanced realities of working with historical data. Rather than working from the perspective of imposed periodizations, it would be more appropriate for a historical database to do away with a periodization scheme and instead code each individual datum for its date, region, significance, etc. By coding individual units, historical nuance, gradation, and gradual development are allowed to emerge naturally from the data itself.

This problem becomes more acute when the periodizations in question stem from uncritical constructions of the historical record. The Latium NGA, for example, follows a traditional and largely conventional set of historical dates; this is especially true for the periods that pre-date the turn of the eras, which include period markers such as $716 \mathrm{BCE}$ (the traditional date given to Romulus's death, after which Numa Pompilius reigned). The problem is that, from a historical-critical perspective, many of these period markers are very much in doubt-e.g., many historians doubt whether Romulus and/or Numa ever existed. This is an instance of the more general error, frequently committed by non-specialists, of failing to distinguish between emic, mythologized accounts and etic scholarly reconstructions of the past. Moreover, in the case of Latium, the demarcation of these perioddefining dates stems from historical sources that date to the $1^{\text {st }}$ century $\mathrm{BCE}$ and later, thus resulting in a pre-100 BCE periodization structure that reflect the ideology of later historical sources. At one level, then, the Seshat periodization of pre-100 BCE Latium reflects a myth of regional origins as constructed by elite, male citizens of late Republican and early Imperial Rome. It is worth noting that meaningful textual evidence does not begin to emerge in Latium until the $4^{\text {th }}$ century BCE. This means that any meaningful diachronic treatment of the historical record prior to $100 \mathrm{BCE}$ should, by default, consult (and ideally adopt) standard periodization dates used by archeologists (which has not been done). The construction of periods should be tied more to the material record than to the textual record, especially for those periods in which no textual record survives.

\section{Conclusion}

The creation of large-scale quantitative databases of the historical record is a relatively recent phenomenon, and such databases are only going to grow in size and prominence. Properly done, they can be extremely useful in a variety of ways. Besides documenting large-scale trends in cultural evolution, for which purpose they are generally designed, they can be used 
by historians to obtain a quick overview of scholarly opinion on a specific topic, to gain an overview of an unfamiliar field, and as a tool for undergraduate education. If equipped with a well-designed interface, they can also be used to visualize data in a way that affords new insights into historical dynamics across space and time.

However, the worth of any large-scale, synthetic project - whether in the form of large-scale database or in-depth reference work-is fundamentally determined by the depth of expert knowledge used to create the data. In ideal circumstances, data should be expert-driven and based on primary sources; at the bare minimum, it should be based on recent peer-reviewed academic scholarship and overseen by experts in the field. There is a wide range of historical sources that describe human behavior and thought in the past, and research assistants and non-specialists alike can easily find sources that might offer a compelling and easy to digest quick answer to a specific question in the database. Winnowing down such sources to those that are recent and relevant to the topic at hand, though, is a task that can only be performed well by scholars trained in the field. Careless approaches to gathering and coding historical data run the risk of angering and permanently alienating the historians and archaeologists whose enthusiasm and cooperation are crucial to the success of this sort of undertaking. Going forward, the only way large-scale historical databases will succeed is by achieving buy-in from the historical community. ${ }^{9}$

Community-sourced data requires building a community. The creation of historically-rigorous data requires the involvement of historians at the most fundamental level. The era of Big Historical Data has arrived. Historians can respond by burying their heads in the sand and hoping it will go away. We feel, however, that a much more useful and effective strategy is to engage with this development and bring it into line with our sense of scholarly integrity and historical accuracy. This will require engaging with new digital platforms and accepting novel forms of scholarly production.

\footnotetext{
${ }^{9}$ We believe that platforms such as the DRH provide an alternative model to Seshat, as well as a better vision of how historical scholarship and digital platforms can work together synergistically. The DRH is the first example of large-scale qualitative-quantitative database run by, and for, historians and archaeologists, with an Editorial Board of over twenty scholars. A reflection of the role of historians in its creation, the DRH is an immensely flexible platform where entries are created on specific units of analysis, such as groups, sites, rituals or texts, with potentially hundreds of entries overlapping in any given slice of space and time. This allows an accurate and nuanced picture of the cultural historical record to emerge by aggregating multiple data points.
} 
Done properly, this will serve to enhance, rather than erase, the role of properly-trained historians in public discourse about humanities' past.

\section{References}

Ambasciano, L., and T. J. Coleman III. 2019. "History as a Canceled Problem? Hilbert Lists, du Bois-Reymond's Enigmas, and the Scientific Study of Religion." Journal of the American Academy of Religion 1fz001. Published: 19 February 2019. https://doi.org/10.1093/jaarel/1fz001

Frayne, D. 1993. Sargonic and Gutian Periods (2334-2113 BC). The Royal Inscriptions of Mesopotamia, Early Periods, Vol. 2. Toronto: University of Toronto Press.

Halton, C., and S. Svärd. 2018. Women's Writing of Ancient Mesopotamia an Anthology of the Earliest Female Authors. Cambridge, UK: Cambridge University Press.

Jennbert, K., and C. Raudvere (eds). 2006. Old Norse Religion in LongTerm Perspectives. Origins, Changes and Interactions. Lund: Nordic Academic Press.

Keown, D. 2013. A Very Short Introduction to Buddhism. Oxford: Oxford University Press.

Price, N. 2002. The Viking Way: Religion and War in Late Iron Age Scandinavia. Uppsala: University of Uppsala Press.

Raudvere, C., and J. P. Schjøt (eds). 2012. More than Mythology: Narratives, Ritual Practices and Regional Distribution in PreChristian Scandinavian Religions. Lund: Nordic Academic Press.

Shattuck, C. 1999. Hinduism. Religions of the World. London: Routledge.

Slingerland, E., Q. D. Atkinson, C. Ember, O. Sheehan, M. Muthukrishna, J. Bulbulia, and R. D. Gray. Under Submission. "Five Challenges for a Comparative Science of Culture," Nature Human Behavior.

Sundqvist, O. 2015. An Arena for Higher Powers: Ceremonial Buildings and Religious Strategies for Rulership in Late Iron Age Scandinavia. Leiden: Brill.

Turchin, P., T. E. Currie, H. Whitehouse, P. François, K. Feeney, D. Mullins, D. Hoyer, C. Collins, S. Grohmann, P. Savage, G. Mendel- 
Gleason, E. Turner, A. Dupeyron, E. Cioni, J. Reddish, J. Levine, G. Jordan, E. Brandl, A. Williams, R. Cesaretti, M. Krueger, A. Ceccarelli, J. Figliulo-Rosswurm, P.-J. Tuan, P. Peregrine, A. Marciniak, J. Preiser-Kapeller, N. Kradin, A. Korotayev, A. Palmisano, D. Baker, J. Bidmead, P. Bol, D. Christian, C. Cook, A. Covey, G. Feinman, Á. D. Júlíusson, A. Kristinsson, J. Miksic, R. Mostern, C. Petrie, P. Rudiak-Gould, B. ter Haar, V. Wallace, V. Mair, L. Xie, J. Baines, E. Bridges, J. Manning, B. Lockhart, A. Bogaard, and C. Spencer 2018. "Quantitative historical analysis uncovers a single dimension of complexity that structures global variation in human social organization." Proceedings of the National Academy of Sciences 115(2): E144. https://doi.org/10.1073/pnas.1708800115

Whitehouse, H., P. François, P. E. Savage, T. E. Currie, K. C. Feeney, E. Cioni, R. Purcell, R. M. Ross, J. Larson, J. Baines, B. ter Haar, A. Covey, and P. Turchin. 2019. "Complex Societies Precede Moralizing Gods Throughout World History." Nature. Published: 20 March 2019. https://doi.org/10.1038/s41586-019-1043-4 


\title{
Supplementary Information
}

\section{S1: Specific Examples of Errors in Coding in the Seshat Databank}

\author{
Edward Slingerland, Department of Asian Studies, University of British Columbia \\ M. Willis Monroe, Department of Asian Studies, University of British Columbia \\ Brenton Sullivan, Department of Religion, Colgate University \\ Robyn Faith Walsh, Department of Religious Studies, University of Miami \\ Daniel Veidlinger, Comparative Religion and Humanities, California State University, Chico \\ William Noseworthy, Department of History, McNeese State University \\ Kate Kelley, Department of Classical and Near Eastern Studies, University of British Columbia \\ Conn Herriott, Institute of Archaeology, Hebrew University of Jerusalem \\ Ben Raffield, Department of Archaeology and Ancient History, Uppsala University \\ Janine Larmon Peterson, Department of History, Marist College \\ Gretel Rodríguez, History of Art and Architecture, Brown University \\ Karen Sonik, Department of Art and Art History, Auburn University \\ William Green, Department of Religious Studies, University of Miami \\ Frederick S. Tappenden, St. Stephen's College, at the University of Alberta \\ Rachel Spicer, Department of Psychological and Behavioural Science, London School of \\ Economics
}

As one would expect from the general remarks in our response to Whitehouse et al., the quality of the Seshat data is extremely variable. Properly and rigorously coded variables in particular polities sit next to completely arbitrary and unreliable ones. Here we provide some representative cases examples of specific errors in coding from a few select NGAs. Given the fundamental and pervasive problems in coding practice described above, however, similar problems can be found throughout the backing data.

\section{Middle Yellow River Valley (Edward Slingerland)}

Beginning in the Western Zhou (1122 BCE), the crucial religion variables related to supernatural punishment and morality are all coded as "unknown," based on the personal communication from Barend ter Haar (a late imperial China specialist) that "very little is known about the relationship between the Chinese and their gods before the arrival of Buddhism". This is a frankly absurd statement: beginning in the Western Zhou we have rich textual materials-both received and archaeologically-recovered texts - that discuss in great detail the relationship between humans, the high god (Tian or Shang Di), various Nature and other deities, and the 
ancestral spirits. None of the relevant primary or secondary material was consulted; even relevant entries in the Database of Religious History (DRH; religiondatabase.org), which code for these very variables, were ignored. This personal communication from ter Haar continues to serve as the basis for coding these variables as "unknown" until the Eastern Han (219 CE), spanning periods such as the Warring States, which produced entire treatises on the role of supernatural punishment in enforcing human morality (again, including both received texts, such as the Mozi, and recently-discovered archaeological texts). Absolutely no research was done by the RA to code these variables; this erroneous initial coding was simply pasted into multiple subsequent polities.

Western Zhou also marks the first appearance of a standard two phrases about ritual frequency, one a brief quotation from a 1988 article, one a personal communication from Connie Cook, a pre-Qin China expert. Cook's cryptic comment, “60 day intervals between rituals," was, as she has subsequently explained in an email (personal communication to Slingerland March 12, 2019), a reference to a Shang Dynasty practice. For some reason is it missing from the Late Shang coding, but appears here and then is simply pasted in as the basis for the ritual frequency coding for every polity from the Western Zhou (1122 BCE) to the Ming (1643 CE), a span of close to 3,000 years. To put this another way, the ritual frequency variable coding from the Zhou to the Ming has nothing to do with any actual scholarship on these regions and time periods.

Throughout the MYRV coding of the religion and ritual variables, a couple personal communications from experts and 3-4 passages from secondary scholarship are continuously pasted into subsequent polities. For instance, Mark Edward Lewis' observation about supernatural enforcement of covenants is used to code a variable in the Western Zhou (which is appropriate), but then simply pasted into and used as the basis for coding all later polities through the Eastern Han $(219 \mathrm{CE})$. There were complex and important transformations in religious thought during this time period, all of which is erased by this clumsy and superficial approach to the historical record.

It is not until the Northern Wei (386-557 CE) that we see another burst of research on the RA's part. The supernatural punishment variables now get new codings based on some very general and basic introductory textbooks to Buddhism. Puzzlingly, Connie Cook's observation about a late Shang ritual practice continues to form the basis for coding ritual frequency. The new vague generalities about Buddhism in China then constitute the basis of coding of the supernatural punishment variables for the rest of Chinese history, that is, through the end of the late Qing (1912 CE).

We performed a re-coding of the 5 religion and ritual variable for 12 early polities in the MYRV, from the Late Shang to the Late Tang, using expert-generated or expert-vetted coding from the Database of Religious History (DRH). Of the 60 variables that overlapped, we found that fewer 
than a third of the Seshat codings were correct, according to DRH data (see summary table 1 below; full data available at:

https://docs.google.com/spreadsheets/d/1YmwqRdDGw4pV1SW1vkAfiob294tT7gQu_S2t5I0v Qdo/edit?usp=sharing).

\begin{tabular}{rlcc}
\hline Seshat NGA & Date & DRH Entries & Agreement \\
\hline \hline Late Shang & $1250-1045 \mathrm{BCE}$ & 3 & $6.67 \%$ \\
\hline Western Zhou & $1122-771 \mathrm{BCE}$ & 2 & $30 \%$ \\
\hline Jin & $794-489 \mathrm{BCE}$ & 1 & $40 \%$ \\
\hline Wei & $488-223 \mathrm{BCE}$ & 6 & $25 \%$ \\
\hline Imperial Qin & $338-207 \mathrm{BCE}$ & 6 & $25 \%$ \\
\hline Western Han & $202 \mathrm{BCE}-9 \mathrm{CE}$ & 5 & $45 \%$ \\
\hline Eastern Han & $25-220 \mathrm{CE}$ & 5 & $31 \%$ \\
\hline Western Jin & $263-317 \mathrm{CE}$ & 2 & $0 \%$ \\
\hline Northern Wei & $386-534 \mathrm{CE}$ & 3 & $40 \%$ \\
\hline Sui & $581-618 \mathrm{CE}$ & 1 & $40 \%$ \\
\hline Early Tang Dynasty & $617-763 \mathrm{CE}$ & 3 & $40 \%$ \\
\hline Late Tang Dynasty & $763-907 \mathrm{CE}$ & 2 & $40 \%$ \\
\hline & & Total & $30.22 \%$ \\
\hline
\end{tabular}

Table 1. Tabulation of Seshat RA-generated codings of religion and ritual variables checked against DRH expert-generated or vetted codings

\section{Susiana (M. Willis Monroe and Kate Kelley)}

With regard to specific coding errors, the entry on the Achaemenid Empire codes all three "supernatural enforcement" questions as "unknown" leaving a gap in their data set. For the same period, an entry in the Database of Religious History (DRH; religiondatabase.org) by 
Amirardalan Emami (https://religiondatabase.org/browse/424/) demonstrates that in all three cases they can be answered in fact as "present." Emami cites royal inscriptions where the god Ahuramazda punishes bad deeds and rewards good deeds.

For the Susa III period (3100 - 2675 BCE) the citations mostly stem from examples used in the preceding Susa II period or constitute general claims about the entire 3rd millennium in Mesopotamia (not Iran). This is an important oversight as the Susa III period is a noted break in iconography and writing culture from the preceding period. A distinct divergent cultural expression with links to highland Iran rather than Mesopotamia was present during this period. Therefore the reference to a "priest-king" during the Susa III period is inappropriate as it is only attested in the Susa II. The absence of this figure has been thought to represent a change in culture and leadership during the Susa III, an important data point for our understanding of complexity.

The slightly later Akkadian period (2270 - 2083 BCE) uses a citation from the Seleucid period (312 - 144 BCE) to provide evidence for frequency of ritual participation. It does not seem appropriate to use a historical observation from the latter part of the first millennium $\mathrm{BCE}$ to create data for the end of the third millennium BCE. Furthermore, this citation is referencing ritual behavior in the city of Uruk in Mesopotamia $700 \mathrm{~km}$ away from Susiana.

Perhaps even more concerning was the level of sloppiness we found in data, which was is disturbingly evident to expert eyes. For example, concerning a period from $3800-2251 \mathrm{BCE}$ encompassing three distinct entries for the NGA representing Susiana one quotation is used repeatedly in support of the measure of religious complexity. This quotation derives from a book about the history of non-European mathematics (Joseph, 2011). However, the quote and its surrounding text are actually concerned with a probable cause for the invention of writing around 3000 BCE in the temple complexes in the city of Uruk in southern Mesopotamia, not Susiana! Even worse, this quotation says nothing about religious complexity; in fact, it's not even about religion. Furthermore, if this source were to be taken at face value and applied wholeheartedly to Susiana despite not covering the time period or the geographical area, it could have been used to attest to the presence of "tokens" for any three of these entries, however all three entries mark the presence of tokens as "?" i.e. unclear. Thus, not only is the citation wrongly applied it is not even consistently applied. This illustration represents the tip of an iceberg of errors, which we've just begun to probe. Our online supplemental highlights \#\# similar cases of sloppiness or inappropriate levels of generalization.

\section{Iceland (Ben Raffield)}

In compiling the entry for the 'Icelandic Commonwealth', the creators of the Seshat database are attempting to deal with a complex historical and religious narrative. The entry follows generally- 
accepted literary and historical accounts that report the colonisation of the island during the 9th century, the establishment of the Alpingi during the 10th century, and the adoption of Christianity by the Icelanders in the year 1000. There is little evidence to suggest that those responsible for compiling the entry have attempted to pursue independent research; they instead rely heavily on the eHRAF database, select personal communications, and a few basic historical texts (one of which was written almost a century ago). This demonstrates, from the outset, a worrying lack of concern with wider archaeological and historical debates on the origins and development of Icelandic society. It is even harder to overlook the entries for individual variables, not least those associated with religion and ritual, the compilation of which demands engagement with a wealth of scholarly literature on pre-Christian belief systems, the Christianisation process, medieval Christianity, and the roles of the Church in Scandinavia. Only a quick glance is needed to see that the treatment of the subject matter is far from satisfactory.

It is difficult to highlight specific issues concerning the content of the religion and ritual variables, the reason for this being that the discussion of pre-Christian beliefs is almost nonexistent. The lack of data is apparently justified by a caveat stating that "Norse morality[/"religion"] is relatively poorly understood, especially as much of what we know about Norse beliefs generally was recorded by Christian authors." This statement, at a basic level, holds some truths. Our knowledge of pre-Christian beliefs is indeed fragmentary, and demands a conscious acceptance that the data available to us (much of which was committed to writing during the later medieval period) represents mere echoes of what was an extraordinarily complex and variable ideology. This does not mean, however, that the available data pertaining to preChristian belief systems - of which there is a great amount - should be arbitrarily disregarded. There has been little to no attempt to actually explore pre-Christian beliefs, religious syncretism, or the medieval Church in Iceland, nor to engage with the academic literature dealing with preChristian belief systems in Scandinavia, something which is strange given that the Norse colonists would have brought with them and adapted elements of the broad cultural package of rituals and beliefs that prevailed on the mainland. Only a few cursory references are made to the Eddic sources, obtained from a reliable but somewhat dated introductory text on Old Norse mythology. Suffice to say, this approach is far from sufficient, especially in light of the complex questions that the Seshat database is supposed to address.

The treatment of medieval Christianity and the Church in Iceland is similarly deficient. While the entry acknowledges that the Christianisation process was a protracted process, involving a period of syncretism in which the Icelanders adapted or adopted Christian beliefs alongside traditional belief systems, there is no detailed discussion of this. It is painfully clear that those responsible for compiling the entry have not even attempted to engage with archaeological literature, which is essential for understanding processes of religious change not only in Iceland but also across the wider arena of the Viking diaspora. The discussion of medieval Christianity itself fares little better and, with the exception of a few references to introductory scholarly texts, 
consists of data obtained from The New Catholic Encyclopedia. There is of course no need to dwell on the many problems associated with this approach, and it is worth noting that at least some of this data seems to have been pasted, in a slightly expanded form, into the entry for the 'Kingdom of Norway' (i.e. Iceland after $1262 \mathrm{CE}$ ). Once again, those compiling the entry have failed to engage with the wealth of available literature on the Christianisation process and the medieval Church in Scandinavia (or, indeed, the many scholarly publications concerning Christianity on Iceland itself). While in some cases there would need be an element of extrapolation involved in this discussion - something that could be offset by a simple caveat acknowledging the limitations of the available data, this material is hardly inaccessible. It is concerning, then, that such a vast subject has been almost totally ignored.

The study of past religious beliefs and practices is a challenging task. While we cannot hope to ever fully reconstruct the prehistoric belief systems of Scandinavia, archaeological, historical, and literary sources offer detailed insights into beliefs and practices as they may have manifested across and between communities. The DRH attempts to integrate these sources in such a way that they can be used to address complex historical questions. The involvement of specialists in the project also serves to mitigate for the potential problems that inevitably arise when attempting to code and characterise diverse beliefs and ritual behaviours. While the resulting entries cannot be considered to be perfect, the DRH demonstrates that it is possible to maximise the potential of the available data by developing polls that are continuously edited and updated through interaction with our peers.

\section{Latium and Eastern Roman Empire/Byzantine (Janine Larmon Peterson)}

The polity defined as "Latium" is inherently problematic. Latium (or Lazio) is a region including Rome, what will be Vatican City, and areas to the west and south, some of which was included in the medieval Papal States and some of which was not. The other, more extensive areas of the Patrimony of St. Peter, later known as part of the Papal States, which extended even further north and west, is not included in this designation. This geographic polity, therefore, is not precise and does not lend itself to specific data due to constantly shifting boundaries. This becomes clear in the chronological breakdown, which covers Latium during the Roman Empire, the Exarchate of Ravenna (which was a secular polity under the Byzantine emperor as opposed to lands under Lombard kings), the "Republic of St. Peter" (a contentious assignation, argued by one eminent medieval historian), and the Papal States (which did not include all of Latium but included many areas not in this polity designation). Even in the less debatable assignation of the Papal States, deep differences between how more distant areas, such as towns in the March of Ancona, conceived of religious practices in contrast to that imposed by the pope in Rome (or in Avignon for the majority of the fourteenth century) is elided. What the entry in Seshat really is 
addressing is Rome and the lands Roman popes claimed as part of their territorial domain. Since the pope in Rome functioned not just as a religious leader but as a terrestrial feudal lord, focusing on the polity in a more circumscribed way, such as "Rome and its contado" (or countryside under Rome's direct control), would erase the anachronistic terms and issues identifying whether secular or church officials had control of the region. The entry for Latium also overlaps with that of the Roman Empire, further muddying the polity designation. Entries on the "Ostrogothic Kingdom" for Latium continue on to entries on the "Eastern Roman Kingdom" and "Byzantine Empire" (I and II), if one does not go back to the original page. These political and geographic leaps of faith suggests Latium was under both papal rule and Byzantine rule at the same time and conflates several very different political polities.

Christianity in Rome and its environs and in Constantinople and its environs clearly cannot be elided. The Great Schism between the Eastern and Western churches (1054), following centuries of discord over institutional and doctrinal disputes, make this fact abundantly clear.

Unfortunately, it is not clear to users of the Seshat database due to the polity designations and practices of data pasting and data filling. Every single entry in the "Religion and Rituals" section for Latium from 312-1527 (although Christianity existed well before Constantine's conversion, here dated to 312) and the Eastern Roman Empire/Byzantine empire from 395-1204 (although the empire continued through 1453 when Constantinople succumbed to the Ottoman Turks) is exactly the same. All of the entries about "supernatural enforcement" of reciprocity, group loyalty, and fairness, and that of "high gods," are based on three quotes from two encyclopedias. These three quotes are the defining - and sole - explication of Roman Catholic and Eastern Orthodox Christianity, as well as all the other forms of Christianity that existed in these regions pre- and post-, such as Arianism, Montanism, Nestorianism, Gnosticism, Donatism, Monophysitism, and other sects before church councils officially condemned their beliefs. Later religious movements that affected the Latium region, such as the Patarines, Cathars, and even Protestants are absent. Even more troublesome is the fact that in an earlier coding variable about social complexity labeled "Religious Levels," for the Byzantine entries the pope in Rome is stated to be "primus inter pares [first among equals] among the five patriarchs" from all chronological designations from 395-1204. The historical inaccuracy of this claim cannot be overstated. The pope was never accepted as the highest of the Patriarchs from any of the other Patriarchs in late antiquity and the medieval period. As noted, the Roman Pope and the Patriarch of Constantinople excommunicated each other (and refused to recognize the validity of the other's excommunication) in 1054, prompting a schism that has continued to this day. Finally, while there were five patriarchs until 927, there were more after that date. The Eurocentric focus on the primacy of Rome within entries about the Eastern Roman/Byzantine Empire is deeply concerning, as is the Christocentric focus of the entry on Latium, which does not recognize at all the robust Jewish population in Rome. 
There are other methodological that promote classism, in terms of focusing on solely the religious elite, besides the Eurocentrism and Christocentrism noted above. These include the misleading statement that religious "participation" was daily, based on this quote: "Swanson, writing of the period after 1215, has noted that "How it [the Mass] fits into a liturgical round is not easily considered, for masses were celebrated with almost mind-boggling regularity and in incalculable quantities'." Unfortunately, this quote is used to describe both lay and clerical participation in Christianity in Latium from the time of the Exarchate of Ravenna (568 CE) through the Renaissance. The Roman Church never imposed daily mass on participants. It was not until the Fourth Lateran Council (1215) that it even required Christians to go to confession once a year. There are also historical inaccuracies. One example is the astounding claim in the "Papal States (1198-1308)" entry that Pope Innocent III (d. 1216 CE) was "the king-maker of Christendom," such as for the Holy Roman Emperor, Frederick II. In fact, Innocent III crowned Otto of Brunswick emperor in 1209 while guardian of Frederick, who was already elected "King of the Germans." Only later did he lend his support to Frederick, circa 1214. It was Pope Honorius III who ultimately crowned Frederick II Holy Roman Emperor in 1220.

Religion, in its institutional, doctrinal, and ritual aspects, is constantly evolving. Databases are a tool that can allow researchers to trace these changes, rather than presenting religion as monolithic over place and time. Seshat's reliance on generic sources pasted across wide spans of space and time makes it an unhelpful tool for this purpose. Seshat has the laudable goal of "describing large-scale human social evolution," and the database is intended as a tool to aid and promote the initial stages of comparative history across time and place by organizing and simplifying data based on common variables. While expertly-vetted and carefully-curated entries could achieve this aim, currently Seshat undermines its own and other attempts at collating such data due to its practice of using tertiary sources and applying brief snippets from these sources across wide swathes of time and place. This practice promulgates a false belief in a static Christian religiosity and organization, which is extremely misleading for inexpert users and not useful for academic researchers

\section{Konya Plain (Conn Herriott)}

Examining the Konya Plain NGA, what immediately jumps out is that the Epipalaeolithic period is entirely ignored, despite evidence at important sites such as Pınarbaşı (e.g., Baird et al. 2013) and Direkli Cave (Arbuckle and Erek 2012). By discounting the foragers of earlier prehistory, Seshat has dismissed from its databank and enormous and critical part of the spectrum of human diversity, which must skew analysis drastically. However, setting this aside and turning to the succeeding Early Neolithic period, very few scholarly references are given, and only general works and communiqués. Unsurprisingly, this resulted in very little actual information being provided, with many blanks in the databank. No use was made of the key research for the main archaeological sites (Baird et al. 2012), or the most important scholarly discussions. 
There is a deeper problem. Seshat works from the premise that prehistoric sites in the Konya Plain can be treated as a group in any sense. This is fundamentally flawed. Indeed, the same is true of many regions. Therefore even if Seshat's data-gathering had been based on careful and exhaustive research, such a perspective would always produce data that mask so much variability as to be virtually meaningless.

\section{Orkhon Valley (Brenton Sullivan)}

Looking at a single polity, the Late Qing, via its connection with the Orkhon Valley NGA (in what is today Xinjiang) raises immediate confusions, because the data under Late Qing barely mentions Mongolia and that data has nothing to do with society in the Orkhon Valley.

In coding the religion and ritual variables for this entry, the RA decided to make Buddhism alone the religion of this polity, which is an oversimplification; moreover, the Buddhism they are coding is a rather normative, book-bound Buddhism. For example, regarding religion's contribution to group loyalty, they cite a theologian's introductory textbook to Buddhism. In addition to the errors noted above concerning the use of temporally- and geographicallyirrelevant sources in their coding, they also cite a 1989 article by Laurence Thompson regarding Buddhism and supernatural enforcement of reciprocity: "It must be admitted that the Chinese hardly contributed anything to the structure or the punishments of purgatory, but simply took over literally the ideas that had arrived from India." This is indefensible in light of more recent work (e.g., that of Steven Teiser [Teiser, Stephen F. The Scripture on the Ten Kings and the Making of Purgatory in Medieval Chinese Buddhism. Honolulu, HI: University of Hawaii Press, 1994) on Chinese Buddhist conceptions of the afterlife, such as the courts of hell, etc. Strangely, for "[ritual] frequency per participant" they jump to a Manchu imperial ritual performed by the emperor and his family. What in the world does this have to the system of morality described above (the Buddhist, karma-based one that, even there, they get wrong)?

Many of the same comments can likewise be applied to another polity that one can arrive at via its connection with the Orkhon Valley, namely the Zungharian Empire. While the source the use is a reliable tertiary source (Christopher Atwood's Encyclopedia of Mongolia and the Mongol Empire), it does not make sense to link the Zunghar polity with this Orkhon Valley NGA, since the Zunghar polity was based in the Ili Valley in what is today Xinjiang.

Regarding supernatural enforcement of reciprocity, the authors cite Rupert Gethin's introductory textbook on Buddhism, which speaks mostly about early or pan-Buddhist notions of morality. While some of this is surely applicable to Zungharia, there are more appropriate treatments of Tibetan Buddhism and even of Mongolian and Zunghar religion. Similarly, the fifth-century, South Asian Pali month Buddhaghosa is invoked to discuss "supernatural enforcement of group 
loyalty." The Buddhist notion of "selflessness" seems highly inappropriate here; one would be better off investigating the importance and influence of incarnate lamas in Zungharia, the importance of local mountain and earth gods, the importance of Heaven (Tenggeri), and/or the importance of sacrifice. In fact, most of the information given on Zunghar religion is the same given for the Late Qing polity and is highly inappropriate (e.g. "This can be done by placing food in the bowls of monks as they pass on their daily alms round ...").

Most problematic is the section on High Gods and Supernatural Enforcement of Morality. The former cites a vague and largely irrelevant line from David Keown's Buddhism: A Very Short Introduction. The latter is blank. I am sure that Vesna Wallace, whom I know, would be dismayed to see her name associated with the "verification of key data regarding the earliest appearance of moralizing gods/doctrinal rituals." (Regarding ritual participation, either the data is incomplete or is not displaying properly. It is very difficult to interpret which ritual they are talking about, who participates in it, and then how often they participate in it).

Finally, similar problem exist with the entry for the Khalkhas polity, which, like the above two (Late Qing; Zunghar Empire) are linked to the Orkhon Valley NGA (this time the association seems appropriate). The lack of expertise is visible here, for example, in the citation from a scholarly source that draws from it precisely the wrong conclusion: "Mongolia had so far been shamanist in faith, but in the second half of the sixteenth century it turned definitively towards the Tibetan form of northern (Mahayana) Buddhism. Although the Yüan emperors had adopted Buddhism as the official religion of the empire, it had never gained much currency in Mongolia and, for that reason, the country had long remained almost completely shamanist...perhaps specialised priests inferred absent before 1550 and present afterwards." There were indeed specialist priests prior to 1550 — not just Tibetan Buddhism lamas, but shamans at the state - and local-levels as well as elders who led worship.

\section{Cambodian Basin (Daniel Veidlinger and William Noseworthy)}

As noted above, polities such as Classical Angkor are coded using a very general reference work on Indian Hinduism that has nothing to do with the Southeast Asian context of this NGA, which causes errors such as using a passage is about 5th century BCE India to code variables in 11 th Century CE Cambodia. The Late Angkor Period likewise quotes from basic textbook introductions to Buddhism, using basically the same quotations that they use for Buddhism in the Rattanakosin Period in Siam 500 years later. Furthermore, although during the Late Angkor Period there was a waning of Hinduism and a rise of Theravada Buddhism, it seems very odd to entirely replace the generic Hinduism information with generic Buddhism information. Besides the problem of the information being too general and coming from basic textbooks about Buddhism or Hinduism in early India, this replacement does not account at all for the interesting 
and characteristically Southeast Asian interplay between Hinduism and Buddhism that would have been the actual case on the ground.

Regarding Angkor in the Tonle Sap region, this whole extended entry has some fairly serious data filling from secondary source material that is actually about sites associated in what is now Thailand and applying them to sites in what is now Cambodia, in the post Angkoran periods. The Khmer Kingdom is acceptable, although there are some odd citations. For instance, while JacqHergoualc'h is a notable scholar, and Smithies an accomplished translator, choosing a book that focuses on "The Armies of Angkor" for material for the Khmer Kingdom period is not what an expert vetter would advise. While I'm certain Buddhaghosa was very probably important in all periods of Cambodian history where monastics were studying Theravada, it would be important for the entry to mention that this is material about a Sri Lankan monk, mostly drawn from a general text about "Understanding Buddhism," rather than a source about Buddhism in Cambodia during the Khmer Kingdom period.

Similarly, most of the information for the "Ayutthaya period" is not necessarily information that corresponds to the central region of Cambodia at all. Instead, it is gathered from historians, some of the best in the field admittedly, such as Baker and Phongpaichit, who wrote about what is now Thailand. This is information about the Chao Phraya basin, not about Cambodia, even though we have ample primary literature in translation and secondary literature to write about this part of what is now Cambodia under the rule of Ayutthaya during this period. The occurrence of the record King Ibrahim I, or Ramathipadi I (1614 - 1659), available in English, Dutch, and French scholarly materials, and the prominence of Muslim communities in Cambodia during this period, well recorded in Cambodian Royal Chronicles might surprise whomever put together this entry.

The same goes for the "Rattanakosin period," although the failings here are even more egregious. By the lead up and through the Siamese-Vietnamese war in 1841-1845, there is a dramatic, changing religious landscape in the region under question, including Chinese, Malays, Vietnamese, Thais, Khmers, and so forth (Buddhism, Islam, and traditional religions all at play, not to mention Christianity). This entry represents a great secondary source material for Rattanakosin, and I would highly recommend it to colleagues who want to learn about Thai history. The problem is that this is an entry that is about...Cambodia.

\section{Inconsistencies between Seshat Data and Supplementary Table 2. (Rachel Spicer)}

Inconsistencies between the seshat database (http://seshatdatabank.info/nature/), data provided on GitHub (https://github.com/pesavage/moralizing-gods) and Supplementary Table 2 of Whitehouse et al. (2019). 


\begin{tabular}{|c|c|c|c|c|c|}
\hline Region & Time Period & Variable & $\begin{array}{l}\text { Supplementary } \\
\text { Table } 2\end{array}$ & Database & GitHub \\
\hline $\begin{array}{l}\text { Orkhon } \\
\text { Valley - } \\
\text { Mongolia }\end{array}$ & $\begin{array}{l}\text { Xiongnu } \\
\text { Imperial } \\
\text { Confederation } \\
(209-60 \mathrm{BCE})\end{array}$ & $\begin{array}{l}\text { Written } \\
\text { records }\end{array}$ & $\begin{array}{l}\text { Present } \\
\text { "Chinese } \\
\text { partially } \\
\text { introduced" }\end{array}$ & $\begin{array}{l}\text { Absent "In } \\
\text { several } \\
\text { supercomplex } \\
\text { chiefdoms the } \\
\text { elite attempted to } \\
\text { introduce written } \\
\text { records (e.g. } \\
\text { Hsiung-nu and } \\
\text { Turks), but the } \\
\text { use of the word } \\
\text { 'attempted' here } \\
\text { seems to imply } \\
\text { that they were } \\
\text { unsuccessful." }\end{array}$ & $\begin{array}{l}\text { Present, } \\
\text { Absent }\end{array}$ \\
\hline $\begin{array}{l}\text { Deccan - } \\
\text { India } \\
\text { (Karnataka) }\end{array}$ & $\begin{array}{l}\text { Mauryan Empire } \\
(300-206 \mathrm{BCE})\end{array}$ & $\begin{array}{l}\text { Written } \\
\text { records }\end{array}$ & $\begin{array}{l}\text { Present "The } \\
\text { edicts of } \\
\text { Ashoka were } \\
\text { inscribed in } \\
\text { Brahmi and } \\
\text { Kharosthi." }\end{array}$ & $\begin{array}{l}\text { Polity missing } \\
\text { from database }\end{array}$ & Present \\
\hline $\begin{array}{l}\text { Kachi Plain } \\
\text { - Pakistan }\end{array}$ & $\begin{array}{l}\text { Mature } \\
\text { Harappan (2500- } \\
\text { 2101BCE) }\end{array}$ & $\begin{array}{l}\text { Written } \\
\text { records }\end{array}$ & $\begin{array}{l}\text { Present } \\
\text { "Indus/Harappa } \\
\text { n script" }\end{array}$ & $\begin{array}{l}\text { Present, no } \\
\text { source }\end{array}$ & Present \\
\hline $\begin{array}{l}\text { Kansai - } \\
\text { Japan }\end{array}$ & $\begin{array}{l}\text { Kofun Period } \\
(250-540 \mathrm{CE})\end{array}$ & $\begin{array}{l}\text { Written } \\
\text { records }\end{array}$ & $\begin{array}{l}\text { Present } \\
\text { "Chinese } \\
\text { introduced via } \\
\text { Korea" }\end{array}$ & $\begin{array}{l}\text { Absent (250- } \\
\text { 399CE) } \\
\text { Absent (399- } \\
\text { 449CE) Present } \\
\text { (399-449CE) } \\
\text { Present (450-710 } \\
\text { CE) } \\
\text { "To all } \\
\text { appearances, } \\
\text { writing as such, } \\
\text { in the form of } \\
\text { Chinese } \\
\text { Classics, was } \\
\text { introduced into } \\
\text { Japan early in } \\
\text { the fifth century }\end{array}$ & $\begin{array}{l}\text { Inferred } \\
\text { Absent (250- } \\
399 \mathrm{CE}) \\
\text { Absent (399- } \\
449 \mathrm{CE}) \\
\text { Present (399- } \\
449 \mathrm{CE}) \\
\text { Present (450- } \\
710 \mathrm{CE}) \\
{ }^{*} \text { Polity time } \\
\text { period is } \\
\text { coded as } \\
250-537 \mathrm{CE} .\end{array}$ \\
\hline
\end{tabular}




\begin{tabular}{|l|l|l|}
\hline & & $\begin{array}{l}\text { as part of the } \\
\text { great cultural } \\
\text { influx from } \\
\text { Paekche. The } \\
\text { earliest Japanese } \\
\text { imperial } \\
\text { chronicles, that } \\
\text { is, the Kojiki and } \\
\text { the Nihonshoki, } \\
\text { were completed } \\
\text { in AD 712 and } \\
\text { 720, and } \\
\text { included } \\
\text { compilations of } \\
\text { various historical } \\
\text { records as well } \\
\text { as ancestral } \\
\text { legends dating } \\
\text { back to ancient } \\
\text { times". } \\
\text { (250-710 CE) }\end{array}$ \\
\\
\end{tabular}




\section{External Links}

S2: Seshat-Reported Expert Vetting of Religion and Ritual Variables (at time of publication):

https://tinyurl.com/y4fr82dc

S3: Seshat Coding Checked Against DRH Entries:

https://tinyurl.com/y3zqpv46

S4: Seshat PDF Archive from March $13^{\text {th }}, 2019$ :

https://tinyurl.com/y6m3k6rt 